\title{
Peningkatan Pengetahuan Masyarakat Samarinda tentang Penyakit Artritis dan Pemeriksaan Kadar Asam Urat
}

\author{
Increased Knowledge of Samarinda Community about Arthritis Disease and Examination of \\ Uric Acid Levels
}

Rizki Nur Azmi*
Sinta Ratna Dewi
Munawarah
Widya Rahmah
Department of Pharmacy,
Universitas $\quad$ Muhammadiyah
Kalimantan Timur, Samarinda, East
Kalimantan, Indonesia
email: rna121@umkt.ac.id
Kata Kunci
Artritis
Asam urat
Kesehatan sendi
Pengetahuan
Keywords:
Arthritis
Uric acid
Joint health
Knowledge
Accepted: September 2021
Published: January 2022

\begin{abstract}
Abstrak
Perubahan akan terjadi pada tubuh manusia sejalan dengan meningkatnya usia. Perubahan tubuh terjadi sejak awal kehidupan hingga usia lanjut pada semua organ dan jaringan tubuh. Keadaan demikian tampak pula pada sistem persendian yang terkait dengan timbulnya penyakit artritis. Pengenalan terhadap penyakit maupun pengobatan artritis melalui metode penyuluhan perlu dilakukan kepada masyarakat agar dapat memunculkan kesadaran tentang pentingnya menjaga kesehatan sendi. Masyarakat yang menjadi peserta penyuluhan diberikan pre dan posttest terkait penyebab artritis, perbedaan gejala di antara penyakit artritis, pengobatan artritis dan cara mengonsumsinya dengan tepat untuk mengurangi efek samping obat yang dapat terjadi. Berdasarkan analisis skor dari test tersebut didapatkan adanya peningkatan yang signifikan pada pengetahuan masyarakat sebelum dan setelah diberikan penyuluhan. Melalui kegiatan ini, masyarakat juga melakukan pemeriksaan kadar asam urat sebagai skrining awal dari tanda gout yang menjadi salah satu penyakit artritis paling umum ditemui di masyarakat. Dengan demikian, masyarakat menjadi lebih memahami penyakit artritis serta kondisi kesehatan sendinya berdasarkan hasil dari pemeriksaan kadar asam urat.
\end{abstract}

\begin{abstract}
Changes will occur in the human body with increasing age. Body changes arise from early life to old age in all organs and tissues. This condition can also be seen in the joint system associated with arthritis. The introduction of disease and arthritis treatment through extension methods needs to be done to the public to raise awareness of maintaining joint health. People who participate in this awarenessraising program are given pre and posttest related to the cause of arthritis, arthritis treatment, and how to take them appropriately to reduce the side effects of the drugs that can occur. Based on the analysis of the scores from the test, it was found that there was a significant increase in public knowledge before and after the program. The community also checks uric acid levels as an initial screening for gout signs, which is one of the most common arthritis in the community. Thus, the public has a better understanding of arthritis and joint health conditions based on examining uric acid levels.
\end{abstract}

() 2022 Rizki Nur Azmi, Sinta Ratna Dewi, Munawarah, Widya Rahmah. Published by Institute for Research and Community Services Universitas Muhammadiyah Palangkaraya. This is Open Access article under the CC-BYSA License (http://creativecommons.org/licenses/by-sa/4.0/). https://doi.org/10.33084/pengabdianmu.v7i1.2297

DOI:

\section{PENDAHULUAN}

Artritis adalah istilah umum untuk peradangan (inflamasi) dan pembengkakan daerah persendian. Artritis merupakan gabungan kata dari bahasa Latin dan Yunani. Dalam bahasa Yunani, arthron berarti sendi dan itis berasal dari bahasa Latin yang berarti peradangan. Artritis bukanlah penyakit tunggal namun sebutan untuk kumpulan gangguan pada persendian. Terdapat lebih dari 100 macam penyakit yang mempengaruhi persendian dan tipe artristis yang umum diderita adalah osteoarthritis (OA), artritis reumatoid (AR) dan gout (Sokolove \& Lepus, 2013; Lawrence et al., 2008). Gejala artritis yang muncul tergantung pada tipe artritis yang diderita namun secara umum pasien akan mengalami nyeri dan kekakuan pada persendian. Hal ini menyebabkan keterbatasan pasien dalam beraktivitas sehari-hari dan kehilangan kemampuan untuk 
bekerja. Artritis merupakan penyakit nomor tiga yang menjadi penyebab disabilitas bekerja pada orang dewasa di Amerika Serikat (Neogi, 2013).

Berdasarkan data dari tahun 2013 hingga 2015 di Amerika Serikat, didapatkan sebanyak 54,4 juta orang dewasa (22,7\%) di diagnosa mengalami artritis. Berdasarkan data tersebut juga didapatkan prevalensi artritis meningkat seiring bertambahnya usia, sebanyak 7,1\% pada usia 18 - 44 tahun, 29,3\% pada usia 45 - 64 tahun dan $49,6 \%$ pada usia di atas 65 tahun. Diprediksi bahwa prevalensi ini akan meningkat hingga 78 juta orang dewasa (28\%) pada tahun 2040 (Centers for Disease Control and Prevention, 2018). Bertambahnya jumlah kasus seiring dengan meningkatnya usia juga terjadi di Indonesia. Prevalensi pada usia di atas 45 tahun lebih banyak dibandingkan usia yang lebih muda (Andri etal., 2020; Siregar, 2016).

Pada tahun 2018, artritis atau penyakit sendi menduduki posisi ketiga yang memiliki prevalensi kasus terbanyak di Indonesia yaitu 7,30\%, dari seluruh penyakit tidak menular. Penyakit sendi yang dimaksud ialah osteoartritis, gout dan artritis reumatoid (Kementerian Kesehatan Republik Indonesia, 2018a). Secara Nasional, tren penyakit ini telah menurun dari tahun 2013, namun di Provinsi Kalimantan Timur tidak terdapat adanya penurunan yang berarti. Didapatkan prevalensi penyakit sendi di Kalimantan Timur pada tahun 2013 sebanyak 8,2\% dan pada tahun 2018 sebanyak 8,12\%. Di Kota Samarinda yang menjadi ibukota dari provinsi ini didapatkan prevalensi kasus berdasarkan diagnosa dokter ialah 4,78\% (Kementerian Kesehatan Republik Indonesia, 2018b). Banyak pandangan masyarakat yang menganggap sederhana penyakit ini karena sifatnya yang tidak menimbulkan ancamanjiwa, namun sebenarnya artritis justru menjadi penghambat yang mengganggu masyarakat untuk melakukan aktivitas sehari-hari. Kurangnya pengetahuan masyarakat untuk mengenal lebih dalam terkait artritis akan berdampak buruk karena beresiko menyebabkan tubuh berfungsi tidak normal, sendi kaku, sulit berjalan dan menimbulkan kecacatan seumur hidup (Susanti et al., 2016).

Berdasarkan hasil Riset Kesehatan Dasar Tahun 2018, penyakit sendi ini menjadi salah satu penyakit yang menyebabkan disabilitas penduduk Indonesia. Disabilitas yang dimaksud meliputi kemampuan mobilitas atau berpindah tempat, melakukan aktivitas sehari-hari, mengurus diri sendiri, daya ingat, bersosialisasi, pengendalian emosi, konsentrasi, serta adaptasi lingkungan dan sosial. Disabilitas menyebabkan adanya ketergantungan pada orang lain. Di Kota Samarinda, penyakit sendi merupakan penyakit kedua terbanyak yang menyebabkan terjadinya ketergantungan, yaitu 43,74\% pada penduduk lansia, setelah penyakit stroke. Tingkat keparahan pada ketergantungan ini meliputi $0,22 \%$ mengalami ketergantungan total, 0,31\% ketergantungan berat, 2,15\% ketergantungan sedang, dan 41,06\% ketergantungan ringan (Kementerian Kesehatan Republik Indonesia, 2018b).

Dibandingkan dengan penyakit tidak menular lainnya, artritis diketahui lebih meningkatkan angka morbiditas dibandingkan mortalitas. Pendataan prevalensi maupun penyebab kematian penyakit ini di Indonesia, maupun di Kalimantan Timur secara khusus, masih belum tercatat dalam hasil riset. Penelitian terkait mortalitas pada penyakit sendi yang dilakukan di luar Indonesia telah mengamati penyebab kematian pada artritis dari tahun 2004 hingga 2014. Hasil penelitian ini menyatakan bahwa artritis menjadi faktor resiko meningkatnya mortalitas pada pasien dengan penyakit kardiovaskular. Sebanyak $36 \%$ pasien artritis yang meninggal memiliki penyakit kardiovaskular. Menurunnya mobilitas dan aktivitas fisik akibat gejala dari artritis menyebabkan peningkatan berat badan yang pada akhirnya memicu timbulnya atau meningkatnya keparahan dari penyakit kardiovaskular hingga kematian (Turkiewicz et al., 2019). Hubungan mortalitas penyakit sendi dan penyakit kardiovaskular ditemukan pada berbagai jenis artritis meliputi gout, OA dan AR (Kiadaliri et al., 2019a; 2019b).

Penyakit artritis juga erat kaitannya dengan penggunaan analgesik atau anti nyeri pada masyarakat lansia. The American Geriatrics Society Panel on Persistent Pain pada lansia menemukan bahwa nonsteroidal anti-inflammatory drug (NSAID) merupakan obat yang paling banyak digunakan dalam penatalaksanaan nyeri dan peradangan akibat artritis (Ely et al., 2015). Berdasarkan rekomendasi Perhimpunan Reumatologi Indonesia, terapi farmakologis lini pertama dalam penanganan rasa nyeri pada artritis adalah NSAID (Perhimpunan Reumatologi Indonesia, 2020). Obat ini dapat dibeli oleh masyarakat secara bebas tanpa resep dokter, sehingga ditemukan sebanyak 24.496 jenis obat NSAID tersimpan di rumah berdasarkan hasi riset kesehatan dasar di seluruh Indonesia. Penggunaan NSAID di Kalimantan Timur mencapai angka 
sekitar 18\%, dimana tujuan utama dari menggunakan obat tersebut ialah untuk mengatasi nyeri akibat penyakit artritis. NSAID yang banyak digunakan dalam indikasi tersebut ialah NSAID yang bekerja dengan mekanismenon-selektif, seperti asam mefenamat, indometasin, naproksen, piroksikam dan natrium diklofenak (Soleha et al., 2018). Meskipun obat terjual bebas dan mudah ditemui, pengetahuan terhadap penggunaan NSAID golongan ini perlu diperhatikan. Hal ini disebabkan karena adanya efek samping yang dapat mengakibatkan gangguan ringan hingga perdarahan pada saluran cerna dan gagal ginjal (Ely et al., 2015).

Untuk mengetahui pengetahuan masyarakat di Samarinda saat ini, dilakukan pengambilan data pada 52 orang yang berusia di atas 40 tahun dengan kuesioner yang berisi beberapa soal terkait artritis dan pengobatannya. Didapatkan sebanyak 67,3\% yang memiliki skor $\leq 50$ dari total skor 100 poin, yang menandakan masih rendahnya pengetahuan masyarakat Samarinda. Dalam beberapa penelitian terdahulu juga didapatkan hasil yang serupa. Hasil penelitian Sakina (2013) didapatkan sebanyak 65,7\% lansia memiliki pengetahuan kurang baik dan hasil penelitian Susanti et al. (2016) didapatkan $48,5 \%$ lansia memiliki pengetahuan cukup baik. Berdasarkan hal tersebut, maka penting sekali untuk mengenalkan pada masyarakat tentang penyakit ini terkait faktor resiko yang dapat dimodifikasi sehingga dapat mencegah terjadinya gangguan pada sendi, gejala dan perbedaan tipe artritis yang umum diderita (OA, AR, gout) serta pengobatan menggunakan anti nyeri dan efek samping yang dapat ditimbulkan dari konsumsi obat tersebut. Dalam kegiatan penyuluhan ini juga dilakukan pemeriksaan kadar asam urat gratis agar masyarakat tidak hanya memiliki pengetahuan tentang artritis tetapi juga diharapkan menjadi lebih waspada terhadap kesehatan sendinya.

\section{METODE}

Metode yang digunakan dalam kegiatan pengabdian kepada masyarakat ini adalah metode penyuluhan. Metode ini dilakukan dengan memberikan pengetahuan dalam bentuk sosialisasi terkait penyakit dan pengobatan osteoartritis, artritis reumatoid dan gout. Sosialisasi ini dilakukan di dua RT yang berada di Kelurahan Pelita dan Sungai Pinang Luar, Kota Samarinda, Provinsi Kalimantan Timur. Pemilihan dua RT ini didasarkan pada data penduduknya yang Sebagian besar berusia dewasa menuju lansia sehingga menjadi target sosialisasi karena artritis banyak diderita pada orang dewasa. Pelaksanaan sosialisasi tidak dapat dilakukan dengan mengumpulkan warga dalam satu tempat karena dilakukan di masa pandemi covid-19, sehingga pelaksanaan dilakukan dengan sistem door to door selama satu minggu (tanggal 3 - 10 Mei 2020) dan telah mendapatkan izin dari ketua RT setempat. Responden kegiatan ini diambil sebanyak 52 orang dengan kriteria berusia di atas 35 tahun karena usia tersebut memiliki prevalensi kejadian penyakit sendi lebih tinggi dibandingkan usia yang lebih muda (Kementerian Kesehatan Republik Indonesia, 2018a).

Instrumen yang digunakan adalah kuesioner pretest dan posttest untuk mengukur pengetahuan masyarakat dan efek dari kegiatan sosialisasi, serta alat cek kadar asam urat menggunakan Autocheck GCU 3 in 1. Bahan yang digunakan adalah materi tentang pengenalan, faktor resiko, gejala dan tipe, serta pengobatan artritis yang dikemas dalam bentuk booklet dan diberikan pada responden. Analisis statistik yang digunakan berupa uji statistik deskriptif dan komparatif. Uji statistik deskriptif digunakan untuk menggambarkan rata-rata kadar asam urat dan rata-rata jawaban responden pada tiap soal tes. Uji statistik komparatif digunakan untuk melihat pengaruh kegiatan sosialisasi terhadap peningkatan pengetahuan masyarakat, dengan uji Wilcoxon pada skor pretest dan posttest karena data yang diambil berasal dari subjek yang sama dengan pengukuran berulang dan berdasarkan uji normalitas, distribusinya tidak normal (Dahlan, 2016)

\section{HASIL DAN PEMBAHASAN}

Kegiatan pengabdian kepada masyarakat dilakukan pada dua Rukun Tetangga (RT) yaitu RT 11 yang berada di Jl. Kyai Haji Ahmad Dahlan Gang 8 dan RT 17 yang berada di Jl. Lambung Mangkurat Gang Rahmat 1. Warga yang menjadi peserta kegiatan pengabdian di RT 11 sebanyak 23 orang dan di RT 17 sebanyak 29 orang, sehingga total jumlah peserta kegiatan ini adalah 52 orang. Peserta berjenis kelamin perempuan sebanyak 33 orang dan laki-laki sebanyak 19 orang. Rata- 
rata usia peserta adalah 51 tahun dengan usia minimum 40 tahun dan maksimum 85 tahun. Kegiatan pengabdian ini diutamakan pada warga dewasa hingga lanjut karena terkait materi penyuluhan yang penting diketahui oleh masyarakat dengan usia tersebut. Karakteristik jenis kelamin dan usia peserta pengabdian dapat dilihat pada Tabel I.

Tabel I. Karakteristik peserta kegiatan pengabdian

\begin{tabular}{lccc}
\hline Karakteristik & Warga RT 11 (n= 23) & Warga RT 17 (n= 29) & Total (n = 52) \\
\hline Jenis Kelamin & & & \\
Perempuan & $15(65 \%)$ & $18(62 \%)$ & $33(63 \%)$ \\
Laki-laki & $8(35 \%)$ & $11(38 \%)$ & $19(37 \%)$ \\
Usia $($ tahun) & & & 40 \\
Minimum & 40 & 40 & 85 \\
Maksimum & 76 & 85 & 51 \\
Rata-rata & 51 & 51 & \\
\hline
\end{tabular}

Berdasarkan hasil pemeriksaan kadar asam urat peserta (pemeriksaan pada salah satu peserta kegiatan pengabdian terlihat pada Gambar 1), ditemukan sebanyak 38\% peserta memiliki kadar asam urat di atas normal (> $7 \mathrm{mg} / \mathrm{dl})$. Dalam penelitian yang dilakukan Songgigilan et al. (2019), disebutkan bahwa terdapat hubungan yang signifikan antara tingkat pengetahuan masyarakat dengan kadar asam urat dalam darah. Penelitian tersebut menyatakan persentase masyarakat yang memiliki kadar asam urat tidak normal lebih banyak pada kelompok masyarakat dengan tingkat pengetahuan kurang baik dibandingkan kelompok masyarakat dengan tingkat pengetahuan baik (27,5\%). Pengetahuan yang kurang dapat mempengaruhi seseorang untuk memahami cara pencegahan dan proses penyakit artritis (Songgigilan et al., 2019). Hal ini menandakan pentingnya edukasi tentang penyakit peradangan sendi dan pengobatannya serta pemeriksaan kadar asam urat agar warga lebih memahami kondisi kesehatannya. Rata-rata kadar asam urat peserta kegiatan pengabdian ini adalah 6,7 mg/dl, dengan kadar asam urat terendah 4,1 mg/dl dan kadar asam urat tertinggi 12,6 mg/dl. Persentase dan kadar asam urat peserta dapat dilihat pada Gambar 2 dan Tabel II.

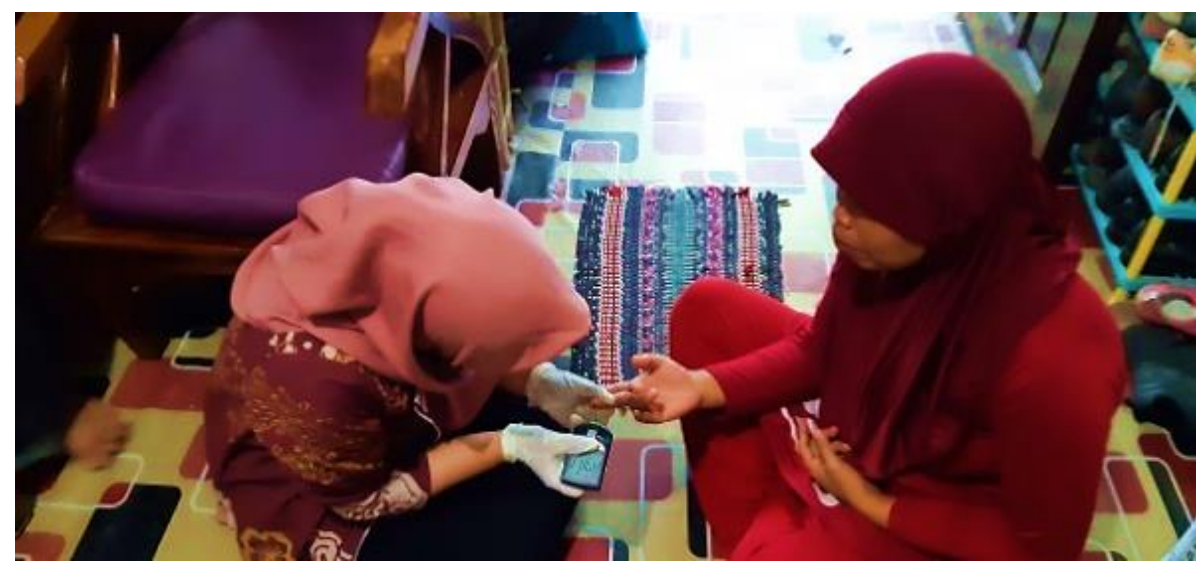

Gambar 1. Pemeriksaan kadar asam urat peserta

Pencegahan suatu penyakit akan lebih diperhatikan oleh seseorang yang mempunyai pengetahuan. Pengetahuan terkait suatu penyakit dapat diperoleh dari berbagai sumber yang diantaranya melalui penyuluhan atau pendidikan kesehatan (Ulfiyah, 2013). Dalam kegiatan pengabdian ini diharapkan adanya peningkatan pengetahuan masyarakat terkait penyakit dan pengobatan artritis meliputi OA, AR dan gout sehingga akan memunculkan kesadaran yang merubah tingkah laku atau pola pikir masyarakat untuk lebih perhatian dengan kesehatan persendian dan memperoleh pengobatan yang aman dan tepat. 


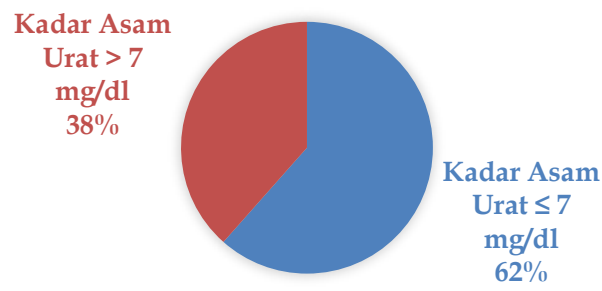

Gambar 2. Diagram persentase kadar asam urat peserta $\leq 7 \mathrm{dan}>7 \mathrm{mg} / \mathrm{dl}$

Tabel II. Kadar asam urat peserta

\begin{tabular}{|c|c|c|c|}
\hline & Minimum & Maksimum & Rata-rata \\
\hline $\begin{array}{l}\text { Kadar asam urat* }(\mathrm{mg} / \mathrm{dl}) \\
\mathrm{N}=52\end{array}$ & 4,1 & 12,6 & 6,7 \\
\hline
\end{tabular}

${ }^{*}$ Kadar asam urat normal berdasarkan referensi pada leaflet alat tes adalah $\leq 7 \mathrm{mg} / \mathrm{dl}$

Pengukuran pengetahuan dapat dilakukan dengan wawancara atau angket yang menanyakan tentang isi materi yang akan diukur dari responden (Notoatmodjo, 2012). Dalam kegiatan ini, pengukuran pengetahuan masyarakat dilakukan dengan pemberian tes sebelum (pretest) dan setelah (posttest) penyampaian materi penyuluhan, Gambar 3 dan 4 menunjukkan penyampaian materi penyuluhan pada peserta dan pengerjaan tes tersebut. Jawaban benar bernilai sepuluh dan jawaban salah bernilai nol. Keberhasilan pemberian materi penyuluhan dapat terlihat pada perbandingan nilai pretest dan posttest.

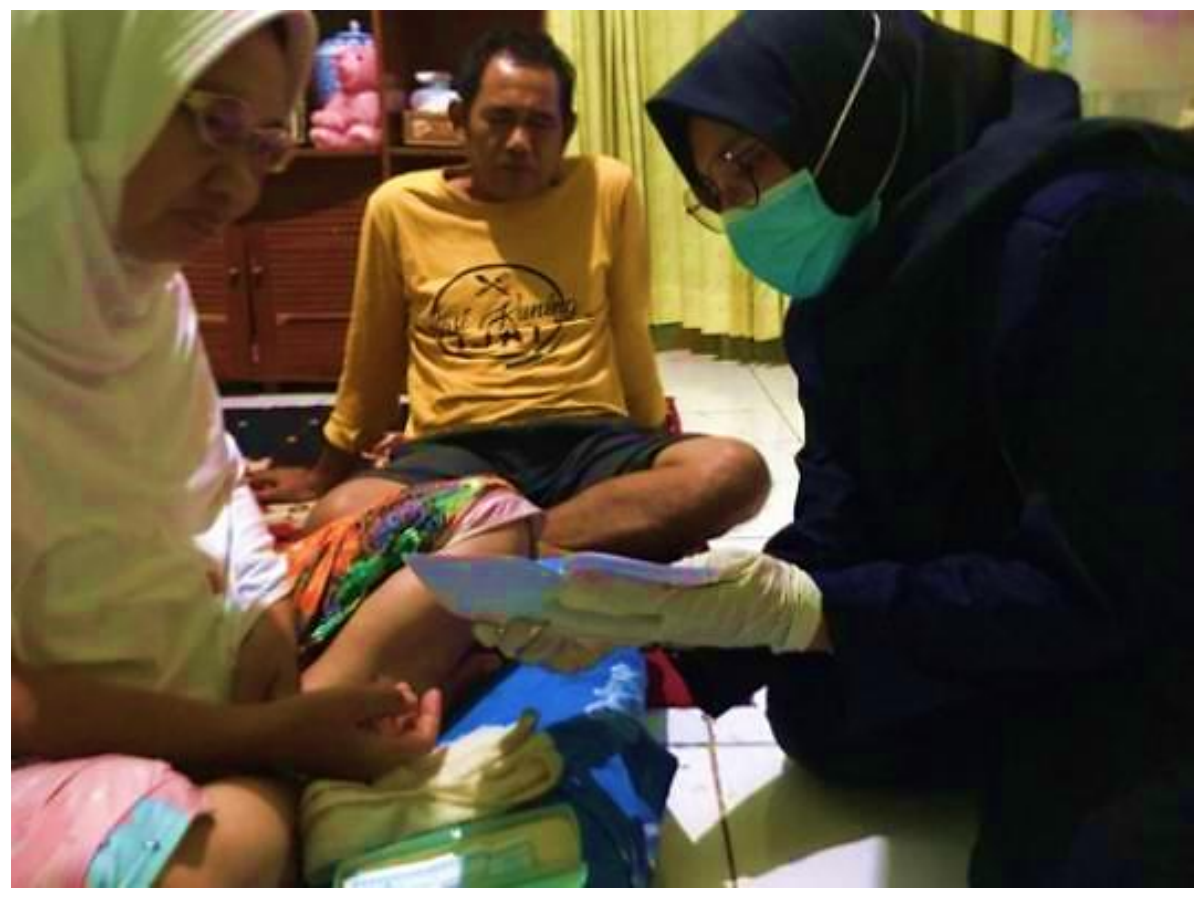

Gambar 3. Penyampaian materi penyuluhan

Hasil pretest menunjukkan pengetahuan umum masyarakat terkait materi penyuluhan dan hasil posttest menunjukkan adanya perubahan pengetahuan setelah diberikan materi penyuluhan. Pada Tabel III dapat dilihat bahwa nilai tengah dari skor pretest adalah 50 dan meningkat menjadi 90 setelah pemberian materi. Berdasarkan analisis secara statistik dengan uji Wilcoxon, didapatkan nilai $\mathrm{p}<0,001$ yang menandakan adanya peningkatan signifikan pada pengetahuan masyarakat terkait penyakit dan pengobatan artritis. 


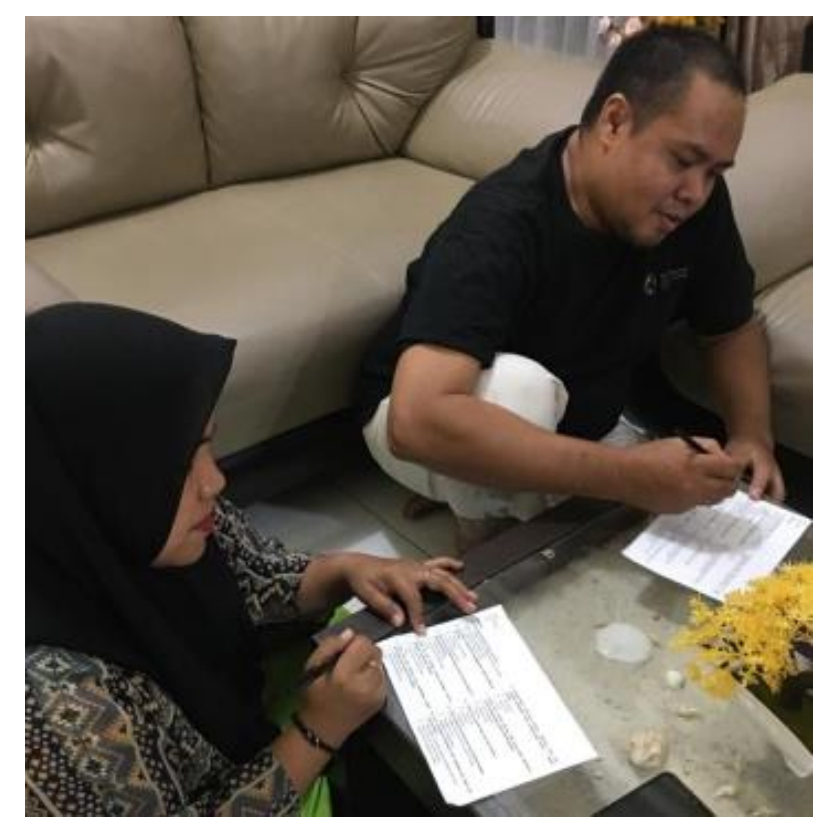

Gambar 4. Pengerjaan tes oleh peserta

Tabel III. Analisis skor pretest dan posttest peserta pengabdian

\begin{tabular}{lcc}
\hline & $\begin{array}{c}\text { Median } \\
\text { (Minimum - Maksimum) }\end{array}$ & Nilai $\mathbf{p}$ \\
\hline Skor Pretest $^{\mathrm{a}}$ & $50(10-90)$ & $<0,001$ \\
Skor Posttest $^{\mathrm{b}}$ & $90(50-100)$ & \\
\hline
\end{tabular}

Uji Wilcoxon, 0 subjek pengetahuan menurun, 2 subjek pengetahuan tetap, 50 subjek pengetahuan meningkat

aTes sebelum dilakukan sosialisasi

bTes setelah dilakukan sosialisasi

Berdasarkan pengamatan pada tiap soal, terlihat bahwa jawaban benar di seluruh soal meningkat setelah pemberian materi penyuluhan. Pada soal nomor 1 - 7 berisi tentang pengertian artritis, jenis dari artritis, cara mencegah peningkatan kadar asam urat dan contoh aktivitas fisik yang dapat dilakukan untuk mengurangi gejala artritis. Pada soal nomor 8 - 10 berisi tentang contoh analgesik, efek samping dan cara mengonsumsinya dengan tepat. Adanya peningkatan jawaban benar pada posttest menunjukkan bahwa pengetahuan masyarakat meningkat baik dari segi materi tentang penyakit artritis maupun tentang pengobatan artritis khususnya analgesik. Grafik peningkatan ini dapat dilihat pada Gambar 5.

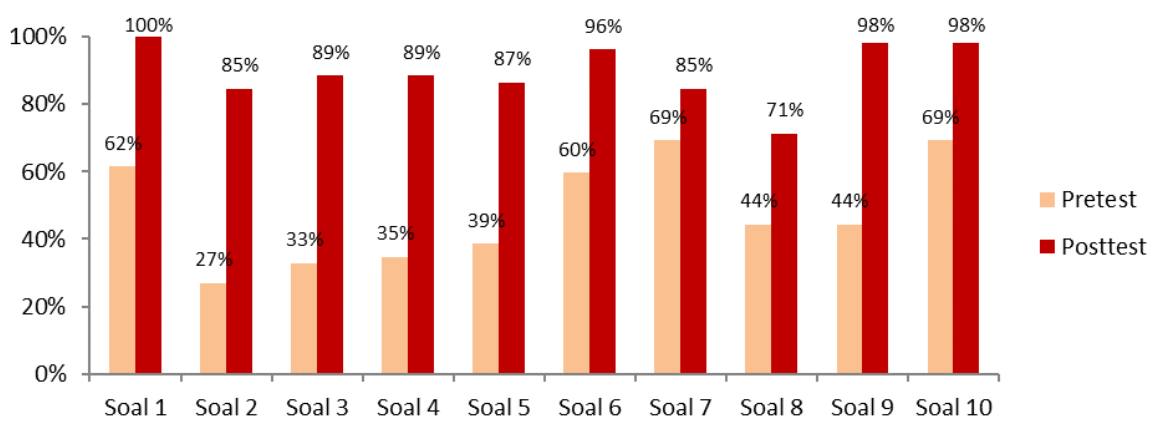

Gambar 5. Peningkatan jawaban tepat pada tiap soal tes

Hasil analisis terkait adanya peningkatan pengetahuan setelah pemberian informasi melalui sosialisasi atau penyuluhan tentang suatu penyakit sesuai dengan beberapa penelitian terdahulu. Dalam penelitian yang dilakukan oleh Susanti et al. (2016), menunjukkan bahwa pengetahuan lansia yang mendapatkan informasi terkait artritis reumatoid lebih baik disbanding yang tidak mendapatkan informasi. Hasil ini juga sejalan dengan hasil penelitian Kurniawati et al. (2014), yang 
menunjukkan bahwa pengetahuan responden yang telah mengikuti penyuluhan kesehatan lebih baik pengetahuannya dibandingkan responden yang tidak mendapat penyuluhan kesehatan. Pengetahuan yang baik dapat memotivasi timbulnya perubahan positif terhadap sikap, persepsi serta perilaku sehat individu atau masyarakat (Notoatmodjo, 2010).

\section{KESIMPULAN}

Penyuluhan tentang artritis diketahui dapat meningkatkan pengetahuan masyarakat di Samarinda terkait penyakit maupun pengobatannya. Pemeriksaan kadar asam urat juga mampu membantu masyarakat untuk mengetahui kondisi kesehatannya. Diharapkan kegiatan penyuluhan ini dapat meningkatkan kesadaran masyarakat pada pentingnya menjaga kesehatan sendi dan cara memperoleh maupun cara mengonsumsi obat nyeri dengan tepat.

\section{UCAPAN TERIMA KASIH}

Ucapan terima kasih penulis haturkan kepada para Ketua RT yang telah memberikan izin dan kesempatan sehingga kegiatan dapat berjalan lancar. Penulis juga mengucapkan terima kasih kepada Universitas Muhammadiyah Kalimantan Timur yang telah memberikan hibah dalam program hibah internal skim Pengabdian IuM (IPTEK untuk Masyarakat) tahun 2020.

\section{REFERENSI}

Andri, J., Padila, Sartika, A., Putri, S.E.N., Harsismanto, J. 2020. Tingkat Pengetahuan terhadap Penanganan Penyakit Rheumatoid Artritis pada Lansia. Jurnal Kesmas Asclepius. 2(1):12-21. https://doi.org/10.31539/jka.v2i1.1139

Centers for Disease Control and Prevention. 2018. Arthritis Related Statistics. https://www.cdc.gov/arthritis/data_statistics/arthritis-related-stats.htm

Dahlan, M.S. 2016. Statistik untuk Kedokteran dan Kesehatan. Edisi Enam. Jakarta: Epidemiologi Indonesia

Ely, L.S., Engroff, P., Guiselli, S.R., Cardoso, G.C., Morrone, F.B., De Carli, G.A. 2015. Use of Anti-inflammatory and Analgesic Drugs in an Elderly Population Registered with a Family Health Program. Revista Brasileira de Geriatria e Gerontologia. 18(3):475-485. http://dx.doi.org/10.1590/1809-9823.2015.14141

Kementerian Kesehatan Republik Indonesia. 2018a. Laporan Nasional Riset Kesehatan Dasar 2018. Jakarta: Badan Penelitian dan Pengembangan Kesehatan Kementerian Kesehatan Republik Indonesia. http://labdata.litbang.kemkes.go.id/images/download/laporan/RKD/2018/Laporan_Nasional_RKD2018_F INAL.pdf

Kementerian Kesehatan Republik Indonesia. 2018b. Laporan Provinsi Kalimantan Timur Riset Kesehatan Dasar 2018. Jakarta: Badan Penelitian dan Pengembangan Kesehatan Kementerian Kesehatan Republik Indonesia. https://dinkes.kalbarprov.go.id/wp-content/uploads/2019/03/Laporan-Riskesdas-2018-Nasional.pdf

Kiadaliri, A.A., Petersson, I.F., Englund, M. 2019a. Educational Inequalities in Mortality Associated with Rheumatoid Arthritis and Other Musculoskeletal Disorders in Sweden. BMC Musculoskeletal Disorders. 20(1):1-6. https://doi.org/10.1186/s12891-019-2465-8

Kiadaliri, A., Moreno-Betancur, M., Turkiewicz, A., Englund, M. 2019b. Educational Inequalities in All-cause and Causespecific Mortality Among People with Gout: A Register-based Matched Cohort Study in Southern Sweden. International Journal for Equity in Health. 18(1):1-10. https:// doi.org/10.1186/s12939-019-1076-1

Kurniawati, E., Kaawoan, A., Onibala, F. 2014. Pengaruh Penyuluhan Kesehatan terhadap Pengetahuan dan Sikap Klien Gout Artritis di Puskesmas Tahuna Timur Kabupaten Sangihe. Jurnal Keperawatan. 2(2):1-8. https://doi.org/10.35790/jkp.v2i2.5210 
Lawrence, L.C., Felson, D.T., Helmick, C.G., Arnold, L.M., Choi, H., Deyo, R.A., et al. 2008. Estimates of the prevalence of arthritis and other rheumatic conditions in the United States. Part II. Arthritis and Rheumatology. 58(1):26-35. https://doi.org/10.1002/art.23176

Neogi, T. 2013. The epidemiology and impact of pain in osteoarthritis. Osteoarthritis and Cartilage. 21(9):1145-1153. https://doi.org/10.1016/j.joca.2013.03.018

Notoatmodjo, S. 2010. Promosi Kesehatan dan Ilmu Perilaku. Jakarta: Rineka Cipta

Notoatmodjo, S. 2012. Metodologi Penelitian Kesehatan. Jakarta: Rineka Cipta

Perhimpunan Reumatologi Indonesia. 2020. Buku Saku Reumatologi. Jakarta: Perhimpunan Reumatologi Indonesia - Keio University

Sakina, A. 2013. Gambaran Pengetahuan dan Sikap Lansia tentang Rematik di Panti Sosial Tresna Werda llomata Kota Gorontalo. Skripsi. Gorontalo: Universitas Negeri Gorontalo

Siregar, Y. 2016. Gambaran Faktor-Faktor Yang Berhubungan Dengan Kejadian Arthritis Rheumatoid Pada Lansia Di Panti Jompo Guna Budi Bakti Medan Tahun 2014. Jurnal Ilmiah Keperawatan IMELDA. 2(2):104-110

Sokolove, J., Lepus, C.M. 2013. Role of inflammation in the pathogenesis of osteoarthritis: latest findings and interpretations. Therapeutic Advances in Musculoskeletal Disease. 5(2):77-94. https://doi.org/10.1177/1759720x12467868

Soleha, M., Isnawati, A., Fitri, N., Adelina, R., Soblia, H.T., Winarsih. 2018. Profil Penggunaan Obat Antiinflamasi Nonstreoid di Indonesia. Jurnal Kefarmasian Indonesia. 8(2):109-117. https://doi.org/10.22435/jki.v8i2.316

Songgigilan, A.M.G., Rumengan, I., Kundre, R. 2019. Hubungan Pola Makan Dan Tingkat Pengetahuan Dengan Kadar Asam Urat Dalam Darah Pada Penderita Gout Artritis Di Puskesmas Ranotana Weru. Jurnal Keperawatan. 7(1):18. https://doi.org/10.35790/jkp.v7i1.24325

Susanti, F., Jamiatun, Sari, E.N.I. 2016. Gambaran Tingkat Pengetahuan Lansia Tentang Reumatoid Arthritis Di RW 01 Kelurahan Pinang Ranti Jakarta Timur. Jurnal Bidang Ilmu Kesehatan. 7(1):401-406. https://doi.org/10.52643/jbik.v6i1.162

Turkiewicz, A., Kiadaliri, A.A., Englund, M. 2019. Cause-specific Mortality in Osteoarthritis of Peripheral Joints. Osteoarthritis and Cartilage. 27(6):848-854. https://doi.org/10.1016/j.joca.2019.02.793

Ulfiyah, H. 2013. Hubungan Antara Tingkat Pengetahuan dengan Perilaku Wanita Menopause dalam Upaya Pencegahan Penyakit Gout di Kelurahan Pisangan. Skripsi. Jakarta: Universitas Islam Negeri Syarif Hidayatullah Jakarta 